\title{
Accounting
}

\section{Comparative significance of human resource management practices on banking financial performance with analytic hierarchy process}

\author{
Quang Linh Huynh ${ }^{a^{*}}$, Thanh Thuy Nguyen Thi', Tan Khuong Huynha, Tuyet Anh Duong Thi and \\ Thuy Lan Le Thi ${ }^{\mathrm{a}}$
}

\begin{tabular}{l}
${ }^{a}$ Tra Vinh University, Vietnam \\
\hline C H R O N I C L E \\
\hline Article history: \\
Received: April 29, 2020 \\
Received in revised format: \\
July 302020 \\
Accepted: August 10, 2020 \\
Available online: \\
August 17, 2020 \\
\hline Keywords: \\
Human resource management \\
Banking financial performance \\
Analytic hierarchy process
\end{tabular}

\section{Introduction}

Separately of the approach followed to identify the indicators of HRM, the empirical literature has provided with sympathetic evidence on causal positive links from HRM to financial performance (Brewster et al., 2018). Nevertheless, only a few quantitative analyses have been undertaken to consider simultaneously the arrangement of these indicators, the organizational contingent factors, in cooperation with the organizational situation where these indicators are adopted and their effects on financial performance. Lately, the main attention to the knowledge of HRM has been to express the significance of efficiently running human resources in businesses. Managerial researchers and practitioners have increasingly focused on learning more about the systems of HRM to improve financial performance (Khalumba, 2012). The last ten years have a growing interest of research in the HRM - performance link, though the hub of research has been occurred in developed economies or the sector of producing. The function of HRM has been as one of the most vital managerial tools. It has been developed in the background of industrial expansion. The exclusivity of human resource entails a wholly diverse sort of focus from business executives. The role of HRM is to offer the largest challenges as well as opportunities. The sector of banking is one of human-intensive because it relies greatly on its human resource to provide banking services to its customers. The practices of HRM play an important role in helping banks to achieve their objectives (Khalumba, 2012). Therefore, it is imperative to investigate the practices of * Corresponding author. E-mail address: huynhquanglinh@tvu.edu.vn (Q. L. Huynh)

(C) 2021 by the authors; licensee Growing Science, Canada doi: $10.5267 /$ j.ac.2020.8.018

\begin{abstract}
Banking financial performance (BFP) has been recognized as a causation of human resource management (HRM). The causal linkages from HRM practices to BFP are different. Nevertheless,
almost none of the studies has ranked and compared this difference among the practices of HRM in enhancing BFP. The current study applied an analytic hierarchy process to rank the relative importance of HRM practices. For the robustness of the results from the process of analytic hierarchy,
the current work employed an analytic hierarchy process to reassess the relatively important levels of HRM practices on BFP as well. The findings are robust across both of the techniques. The practice performance evaluation (PN) and the practice of reward system (RM) as the third most important. In contrast, the practice of recruitment and selection (RN) takes the least important position in BFP. HRM to BFP. This work makes some contribution to how managers should decide on HRM practices in order to obtain the best possible BFP.
\end{abstract}


HRM as well as their effects on BFP in developing economies. Additionally, to the best of the authors' knowledge, no work has assessed the importance of the practices of HRM contributing to BFP. The current research seeks to scrutinize empirically the impacts of HRM practices on financial performance at Vietnamese banks. Principally, it discuses and compares the important extent to which the practices of HRM contribute to BFP there.

\section{Literature review}

Many researchers have emphasized the association between HRM and corporate performance (Lee et al., 2010; Sabiu et al., 2019; Alzyadat et al., 2015; Li et al., 2015). As the abovementioned studies show, the practices of HRM are determinants of corporate performance. Furthermore, Sabiu et al. (2019) highlighted the research of HRM has obtained significance in the management literature for the last decades, and most significantly is its influence on corporate performance. Sheehan (2014) and Alzyadat et al. (2015) emphasized the significance of HRM in business and recommended that the best practice of HRM likely lead to best possible corporate performance. The practice of HRM could be composed of TT, participation, payment and PN (Huselid, 1995; Becker \& Gerhart, 1996). Furthermore, other scholars indicated that enterprises adopting the better practice of HRM would motivate their employees to work better, resulting in advanced corporate performance (Lee et al., 2010; Li et al., 2015). Innovative enterprises consider the practice of HRM as good managerial tools to motivate group responsibilities, and develop good relationships with their consumers via participation and empowerment, which could help renovate products and services. Consequently, it is imperative for an enterprise to employ the best practice of HRM, which could encourage and motivate their workers to be more creative, so that they can create more success to the enterprise. Moreover, Delery and Gupta (2016) analyzed alternative conceptualizations of the linkage from the practices of HRM to organizational efficiency. The research explained an outline to recommend a multifaceted link from the practices of HRM to organizational efficiency, and provided statistical evidence that the practices of HRM could improve organizational efficiency and underline the worth of theory determined procedural methods. Similarly, Asri (2017) explored the role of HRM practices on BFP, and confirmed that the efficient systems of HRM could lead to improve financial performance in banks. Moreover, Quresh et al. (2010) claimed that, the practices of HRM have been increasingly accepted as one of the key contributing forces of BFP. The significance of HRM practices to BFP was analyzed. That research tried to link the practices of HRM to financial performance of banks and discovered a positive linkage from HRM practices to BFP. Overall, it can posit positive influences from the practices of HRM to BFP. The most significant practices of HRM, which are selected for analyses, are RN, TT, RM, and PN. Afterward, the importance of these elements on BFP is discussed.

\subsection{RN on performance}

Recruitment is a practice of collecting competent candidates for vacant situations in an enterprise and coming to a decision whether to take on these candidates (Mathis \& Jackson, 2004); whereas selection entails selecting the most appropriate candidates who meet the necessities for the job, which is a decision-making process of suitability (Price, 2007). Furthermore, Alzyadat et al. (2015) stressed that the development of a firm will call for an increase in the number of employees, so more significance should be paid to the practice of RN. The RN of the best eligible employees to fill vacant positions could be considered as an important goal, not only for the unit of human resource management, but also for various directors in business (Huo et al., 2002). This will result in the conversion of HRM, because efficient practices of HRM initiate with recruitment. The selection of suitable workers indicates a successful response successful to competitors' practices of HRM (Armstrong, 2006). Enterprises, which implement proper practices of RN, are assured to take on workers with the competent skills and qualification for that position (Saifalislam et al., 2014). Privilege procedures of RN have been evidenced as a positive determinant of firm performance (Harel \& Tzafrir, 1999). When advertisement for a job wanted is published, candidates are now and then taken on by word of mouth, through current workers (Kipkorir, 2013). In addition, if the practice of RN receives poor employees to organizational fit, they can leave the enterprise afterward. Accordingly, incompatibleness with work necessities could enable workers to move away the bank, which likely decreases BFP.

\subsection{TT on performance}

According to Vlachos (2009), the process of TT is a vital practice of HRM. The practice of TT stands for the latest evolutionary stage in training, cultivating and developing the resource of human, which help workers to satisfy organizational goals. Additionally, Lee et al. (2010) referred to the practice of TT as an amount of formal training offered to workers. Enterprises could give general formal training and attain needed skills via the process of selection as well as socialization. The process of training is an organized job aiming to convey instructions to help workers enhance their knowledge and skills, whereas the process of development is regarded as the actions enabling workers to achieve new understanding and skills that are required for improving employee performance (Saifalislam et al., 2014). Training likely includes off-job training, on-job training, skill training or literacy training (see Gomez-Mejia et al., 2004). The procedures of comprehensive TT can lead workers to concentrate on skills and knowledge, which help them to attain objectives and produce aggressive improvement for their enterprise. As Apospori et al. (2008) pointed out; the programs of TT could put positive influences on organizational 
performance. The process of TT is aimed at developing industrial, medical and soft skills for instance group working, leadership or interview. Accordingly, improvements in worker skills are a vital feature in the process of organizational management. According to Harel and Tzafrir (1999), the process of TT could affect organizational performance in two ways. The first is that, TT can advance related skills and aptitudes. The second is that the programs of TT likely augment worker satisfaction with existing jobs as well as places of work.

\section{$2.3 R M$ on performance}

Reward, referred to as compensation, is a methodical system to provide financial value to workers in exchange for their job that has been carried out (Khalumba, 2012). The system of reward can attain numerous purposes, which help support recruitment, improve employee performance and satisfaction. The practice of compensation is an instrument employed by managers for various purposes to maintain the development of enterprise and might be adapted to business requirements, objectives as well as availableness of organizational resources. The system of compensation is often applied to take on and maintain competent employees, augment and sustain the confidence of employees, compensate and promote employee commitment. In addition, Frye (2004) scrutinized the link from equally based reward to organizational performance and indicated a positive correlation among them. The system of compensation plays an imperative role in drawing and retaining extremely skillful workers. Delaney and Huselid (1996) asserted that, organizational performance is dependent on the practice of compensation in business, which is one of the most important approaches enterprises apply to improve worker enthusiasm by giving employee performancereliant incentive to align benefits among workers and shareholders. Because, banks are capital concentrated enterprises, the systems of compensation in banks could help to hire and maintain enormously skillful and competent workers. The practice of payment will positively and significantly influence employee performance if it combines with innovative tools such as supple job planning, worker involvement in analytical groups, general supervising, communication and job security, which can lead to financial performance (Ichniowski \& Shaw, 1999). The suitable systems of compensation can put statistically significant effects on employee performance as well as financial performance, and a positive linkage from the systems of compensation to employee and financial performance was revealed (Huselid, 1995).

\subsection{PN on performance}

The evaluation of job performance is needed for all kinds of enterprise, which is employed to ensure the preferred outcomes for the workforce. The qualitative and quantitative procedures are applied to evaluate employee performance (Alzyadat et al., 2015). Additionally, other researchers argued that good systems of performance appraisal could augment the effectiveness of enterprises and there is a propensity for enterprises to be concerned about the efficiency of procedures built up by experts to advance organizational performance (Abu-Doleh \& Weir, 2007; McKenna \& Beech, 2002). Workers at different levels in business are interested in the extent of employee performance, in comparison with expectations by their enterprise. The evaluation of performance is a tool that is applied to address those concerns. In spite of those worries, the systems of PN still remain a vital means utilized to advance overall organizational performance.

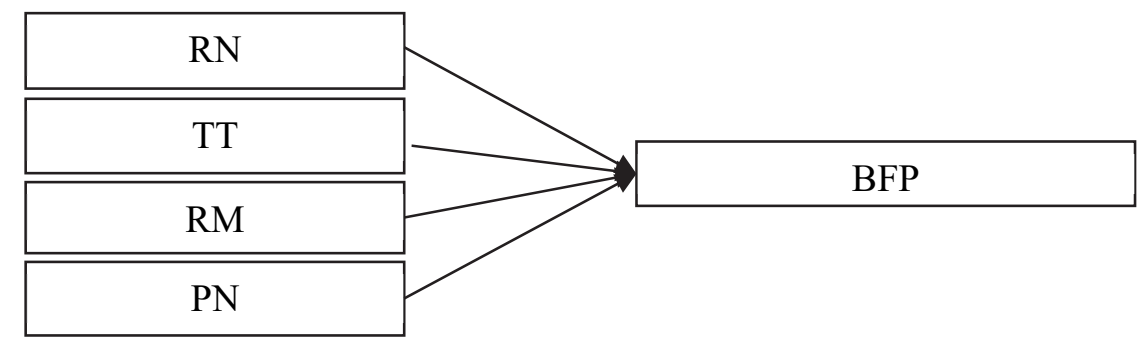

Fig. 1. Research Model

Based on Lee et al. (2010), the evaluation of employee performance is to appraise employee performance, the aim of which is to advance established objectives and accept responses in order that workers can express, adjust and boost employee performance, which is based on outcomes or behaviors of the workers. This can help improve organizational performance. As Sang (2005) indicated, the practice of PN can help top directors to elucidate and to communicate organizational goals and hopes with inside workers, which enables them to understand the ability of their workers. Furthermore, the practice of PN could be employed for managerial purposes that relate to worker's working conditions such as encouragement, termination and rewards (Gomez-Mejia et al., 2004). Nevertheless, various scholars and directors asserted that the evaluation of employee performance leads to discouragement to a workplace and low industrious pace, which is supposed to be removed from business, so a few enterprises should accept this system with care (Lee et al., 2010). Overall, for the banking context the aforementioned discussions could lead the suggestion that the practices of HRM, which are RN, TT, RM, and PN, play a vital role in improving BFP. Then, it can suggest the research model as shown in Fig. 1. 


\section{Methodology}

\subsection{Analytic hierarchy procedure}

To grade the relative magnitude of HRM practices in determining BFP, the method of investigative hierarchy or an analytic hierarchy process was employed. This method is an instrument utilized for multi-criteria evaluation and the analysis of decisionmaking as Saaty (1980) produced. The technique of investigative hierarchy has the prejudiced evaluation of every evaluatingmaker as input and the quantifying power of every alternative as output. This procedure is deemed as a process of compensation decomposing an intricate judging problem into a hierarchy. Paired assessments among all of the selections to one another are utilized to get the weights and scores. The evaluating scale for pair-wise comparisons is revealed in Table 1 . If $X$ is as equally essential in determining the main factor as $\mathrm{Y}$, it is rated at 1 ; whereas if $\mathrm{X}$ is entirely more essential in explaining their factor than $\mathrm{Y}$, then it will be graded with 5 . If $\mathrm{Y}$ is entirely less imperative in determining the main factor than $\mathrm{X}$, then it will be measured at $1 / 5$. It is similar for "more essential- 3" and "intermediary values- 2 and 4 ". The process of analytic hierarchy consists of three steps as stipulated by Saaty (1980). In order for testing the consistence of evaluations, CR (consistency ratio) is applied to appraise how dependable the evaluations are. It is a ratio of CI (consistent index) divided by R $\mathrm{I}_{\mathrm{m}}$ (random index). $R I_{m}$ is created as Saaty (1980) proposed; whereas, CI is a ratio of $\left(\mathfrak{E}_{\max }-\mathrm{m}\right) /(\mathrm{m}-1)$. $\mathfrak{f}_{\max }$ is the maximum eigenvalue; while, ' $\mathrm{m}$ ' is the number of elements required for comparison. As Saaty (1980) suggested, CI and CR need to be smaller than the 0.1 threshold.

Table 1

The rating scale of relative importance of factors

\begin{tabular}{cll}
\hline Force of vitality & Depiction & \multicolumn{1}{c}{ Clarification } \\
\hline 1 & Equally essential & Two elements contributing equally \\
3 & More essential & Evaluations advocate one over the other. \\
5 & Entirely more essential & Evaluations advocating one over the other is of the peak potential strength \\
2,4 & Intermediary values & Compromise required \\
\hline
\end{tabular}

\subsection{Regression analysis}

In order for checking the relative impacts of HRM practices on BFP, the technique of regression analysis was utilized. The analysis of regression is an influential statistical technique, which allows studying the connection between numerous research variables. Whereas there are several kinds of regression analyses, overall, they all explore the impacts of explanatory factors on an explained factor. The analysis of regression offers detailed insight that could be used to further advance BFP. In this research, the analysis of regression was employed to statistically investigate the influences of HRM practices on BFP; and simultaneously reassess the relative magnitude of HRM practices in determining BFP in order for the robustness with the evidence from the procedure of analytic hierarchy. The current study assesses the practices of HRM with four elements, which are RN, TT, RM, and PN (Huselid, 1995; Becker \& Gerhart, 1996). Each of the elements is computed with a single item. BFP is measure on ROE, modified from Huynh (2018) and Lee and Roh (2012).

\subsection{Data collection}

The research population of this project consisted of banks operating in Vietnam, which were totally 94 banks. The first solicitations were undertaken to get feedbacks from key informers in charge of management. Each manager for every selected bank was participated in survey. Of the 94 questionnaires that were delivered, there were only 71 suitable answers for the process of analytic hierarchy. Before collecting the data, a pilot test was performed with 20 directors involved in management to ensure that the scales are valid and suitable for this research (Bowden et al., 2002).

\section{Results}

\subsection{Analytic Hierarchy Process}

After obtaining the 71 suitable answers, an average for every element was undertaken. Then, employing Saaty (1980)'s method, this research attained elemental weights as Table 2 displays. $\mathrm{W}_{\mathrm{i}}$ is equal to the $4^{\text {th }}$ root of product of values. Eigenvector is equal to $\mathrm{W}_{\mathrm{i}} /$ the total of $\mathrm{W}_{\mathrm{i}}$. New vector is equal to $\left[\mathrm{e}_{\mathrm{j} j}\right] \times\left[\mathrm{f}_{1 \mathrm{j}}\right]$; where $\left[\mathrm{e}_{\mathrm{jj}}\right]$ is the matrix of the 4 elements in 4 columns and 4 rows, $\left[\mathrm{f}_{1 \mathrm{j}}\right]$ is the matrix of the eigenvectors in 1 column and 4 rows.

\section{Table 2}

Weights

\begin{tabular}{cccccccccc}
\hline & RN & TT & RM & PN & W & Eigenvector & Rank & New Vector & New Vector/Eigenvector \\
\hline RN & 1.00 & 0.35 & 0.80 & 0.56 & 0.629 & 0.14 & 4 & 1 & 0.56 \\
TT & 2.83 & 1.00 & 3.00 & 2.00 & 2.030 & 0.45 & 3 & 0.82 \\
RM & 1.26 & 0.33 & 1.00 & 0.57 & 0.698 & 0.16 & 2 & 0.63 \\
PN & 1.80 & 0.50 & 1.76 & 1.00 & 1.122 & 0.25 & 1.00 & 4.01 \\
\hline Total & & & & 4.48 & 1.00 & & \\
\hline
\end{tabular}


The figures in Table 2 demonstrate the importance levels that the practices of HRM play in leading to BFP. CI is 0.04, while $\mathrm{CR}$ is 0.04 . Both of them are less than the 0.1 threshold as stipulated by Saaty (1980). These findings indicate all of the tests of consistency are passed. Consequently, the weights are all appropriate for the process of analytic hierarchy. The findings also reveal that, the practice of TT is ranked first, then the practice of PN and the practice of RM are rated the second and third positions. On the contrary, the practice of RN takes the last position.

\subsection{Regression analysis}

The empirical outcomes of the multiple regression are revealed in Table 2. With regard to the effect of HRM on BFP, as can be seen in Table 2, the practices of RN, TT, and RM positively influence BFP at a 5\% significance value, whereas the practice of PN imposes a positive influence on BFP at a $1 \%$ significance value. The research model fits at a $1 \%$ significance level with an F of 16.43 and an $\mathrm{R}^{2}$ of $49.9 \%$, which implies that the practices of HRM depict a $49.9 \%$ variation in BFP. The research model achieves the variance inflation factors (VIFs) of HRM practices of 1.455, 1.377, 1.354 and 1.348 that are less than the preferred level of 2 stipulated by Hair et al. (2011), thereby demonstrating no multicollinearity in the research model. In addition, the coefficient of Durbin-Watson is 1.909 , which ranges from du to $(4-\mathrm{du})$; therefore, it can be concluded that there is no autocorrelation in the analyzed data. The $\mathrm{Chi}^{2}$ of 0.07 with a significance of 0.92 greater than $10 \%$ indicates no heteroskedasticity in the research model. Overall, the research model acquires a good fit for the data. The results are in agreement with those generated from the technique of analytic hierarchy. The practice of TT plays the most significant role in BFP, and then the practice of $\mathrm{PN}$ is the second most important. The practice of RM is the third most important, while the practice of RN comes to the least important position in BFP.

Table 3

Regression Analysis (Dependent Variable: BFP)

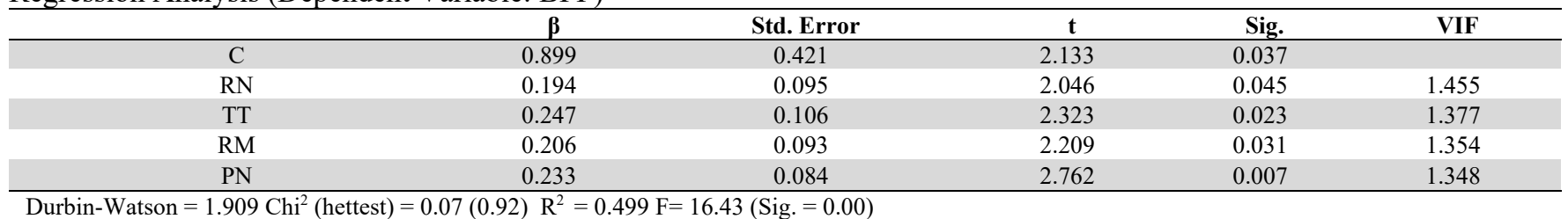

\section{Conclusion}

The causal links from HRM practices to BFP have been explored, while only a few research projects have investigated the relative importance of HRM practices on financial performance in the banking sector, especially in Vietnam's banking sector. The current study attempted to assess the comparative importance of HRM practices in improving BFP by applying the process of analytic hierarchy. It also used the analysis of regression to reassess the relative importance of HRM practices as well as to investigate statistical impacts of HRM practices on BFP. The results from both of the techniques for ranking the relative significance of HRM practices are consistent. The practice of TT plays the most essential role in BFP. Subsequently, the practice of PN is the second most imperative. The practice of RM is the third most essential. Conversely, the practice of RN comes to the least important position in BFP. Furthermore, the findings have also revealed that the practices of HRM all impose statistical effects on BFP. This study provides insight into the comparative importance as well as statistical influences of HRM practices in improving BFP. These results are helpful to managers in Vietnam's banking sector by giving a better understanding of the priority levels of HRM practices leading to higher BFP. Therefore, they can decide on a suitable adopting level of HRM practices in their banks that likely improve BFP.

\section{Acknowledgement}

The authors are seriously thankful to Tra Vinh University for their financial support for the current research (Expressed in Contract No 201/HĐ.HĐKH-ĐHTV) and would like to thank the respondents for their effort to help us in collecting the research data as well.

\section{References}

Abu-Doleh, J \& Weir, D. (2007). Dimensions of performance appraisal systems in Jordanian private and public organizations. International Journal of Human Resource Management, 18(1), 75-84.

Alzyadat, M., Alatyat, Z., \& Alnsour, J. (2015). The impact of human resources management on organizational performance in the greater Amman municipalities, Jordan. International Journal of Applied Business and Economic Research, 13(2), 869-889.

Apospori, E., Nikandrou, I., Brewster, C., \& Papalexandris, N. (2008) HRM and Organizational Performance in Northern and Southern Europe. International Journal of Human Resource Management. 19(7), 1187-1207.

Armstrong, M. (2006). Human Resource Management Practice. Kogan Page, London, UK.

Asri, M. (2017). Effect of human resource on financial performance of Islamic bank in Indonesia. IOSR Journal of Business and Management, 19(12), 32-35. 
Brewster, C.J., Mayrhofer, W., \& Farndale, E. (2018). Handbook of research on comparative human resource management. Cheltenham: Edward Elgar Publishing, UK.

Becker, B., \& B. Gerhart. (1996) The impact of human resource management on organizational performance: Progress and prospects. Academy of Management Journal, 39(4), 779-801.

Bowden, A., Fox-Rushby J.A., Nyandieka L., \& Wanjau J. (2002) Methods for pre-testing and piloting survey questions: illustrations from the KENQOL survey of health-related quality of life. Health Policy and Planning, 17(3), 322-330.

Delaney, J.T., \& Huselid, M.A. (1996). The impact of human resource management practices on perceptions of organizational performance. Academy of Management Journal, 39(4), 949-969.

Delery, J., \& Gupta, N. (2016) Human resource management practices and organizational effectiveness: internal fit matters. Journal of Organizational Effectiveness: People and Performance, 3(2), 139-163.

Frye, M.B. (2004) Equity-based Compensation for Employees: Firm Performance and determinants. The Journal of Financial Research, 27(1), 31-54.

Gomez-Mejia, L.R., Balkin, D.B., \& Cardy, R.L. (2004). Managing Human Resources, Upper Saddle River, NJ: Pearson Prentice Hall, USA.

Hair, J.F., Black, W.C., Babin, B.J., Anderson, R.E. \& Tatham, R.L. (2011). Multiva-riate Data Analysis. New Jersey: Prentice Hall, USA.

Harel, G.H., \& Tzafrir, S.S. (1999). The effect of human resource management practices on the perceptions of organizational and market performance of the firm. Human Resource Management: Published in Cooperation with the School of Business Administration, The University of Michigan and in alliance with the Society of Human Resources Management, 38(3), 185-199.

Huselid, M.A. (1995) The impact of human resource management practices on turnover, productivity, and corporate financial performance. Academy of Management Journal, 38(3), 635-672.

Huo, V.P., Huang, H.J., \& Napier, N.K., (2002) Divergence or convergence a cross national comparison of personnel selection practices. Human Resource Management, 41(1), 31-44.

Huynh, Q.L. (2018). Earnings quality with reputation and performance. Asian Economic and Financial Review, 8(2), $269-278$.

Ichniowski, C., \& Shaw, K. (1999) The Effects of Human Resource Management Systems on Economic Performance: An International Comparison of US and Japanese Plants, Management Science, 45(4), 704-721.

Khalumba, M. (2012) The influence of human resource management practices on financial performance of commercial banks in Kenya (Doctoral dissertation), University of Nairobi, Kenya.

Kipkorir, C. (2013) Effects of Human Resource Management Practices on Financial performance of Selected Agricultural Firms in the Sugar Industry.

Lee, F.H., Lee, T.Z., \& Wu, W.Y. (2010) The relationship between human resource management practices, business strategy and firm performance: evidence from steel industry in Taiwan. The International Journal of Human Resource Management, 21(9), 13511372 .

Lee, J., \& Roh, J.J. (2012). Revisiting corporate reputation and firm performance link, benchmarking. An International Journal, $19(4 / 5), 649-664$.

Li, X., X. Qin, K. Jiang, S. Zhang, \& F.Y. Gao. (2015) Human resource practices and firm performance in China: The moderating roles of regional human capital quality and firm innovation strategy. Management and Organization Review, 11(2), $237-261$.

Mathis, R.L., \& Jackson, J.H. (2004). Human resource management. Thomson Asia Pte Limited, Singapore

McKenna, E. \& Beech, N. (2002). Organisational Culture in Human Resource Management, A Concise Analysis. Prentice Hall, UK.

Price, A. (2007). Human resource management in a business context. Cengage Learning (EMEA) Limited, UK.

Quresh, T.M., Akbar, A., Khan, M.A., Sheikh, R.A., \& Hijazi, S.T. (2010) Do human resource management practices have an impact on financial performance of banks?. African Journal of Business Management, 4(7), 1281-1288.

Sabiu, M.S., Ringim, K.J., Mei, T.S., \& Joarder, M.H.R. (2019) Relationship between human resource management practices, ethical climates and organizational performance, the missing link. PSU Research Review, 3(1), 50-69

Saifalislam, K.M., Osman, A., \& AlQudah, M.K. (2014) Human Resource Management Practices: Influence of recruitment and selection, and training and development on the organizational performance of the Jordanian Public University. IOSR Journal of Business and Management, 16(5), 43-46

Sang, C. (2005). Relationship between HRM Practices and the Perception of Organizational Performance, Roles of Management Style, Social Capital, and Culture: Comparison between Manufacturing Firms in Cambodia and Taiwan, unpublished Master's thesis, National Cheng Kung University, Taiwan

Saaty, T.L. (1980). The Analytic Hierarchy Process. New York, McGraw-Hill, USA

Sheehan, M. (2014) Human resource management and performance: Evidence from small and medium-sized firms. International Small Business Journal, 32(5), 545-570

Vlachos, I.P. (2009) The effects of human resource practices on firm growth. International Journal of Business Science and Applied Management, 4(2), 17-34

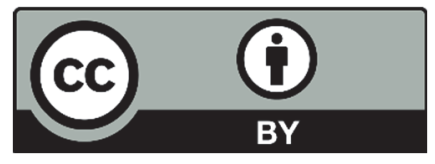

(C) 2020 by the authors; licensee Growing Science, Canada. This is an open access article distributed under the terms and conditions of the Creative Commons Attribution (CC-BY) license (http://creativecommons.org/licenses/by/4.0/). 